\title{
Association between food consumption and high levels of low density lipoprotein cholesterol among obese children
}

Związek między spożyciem żywności a wysokim stężeniem cholesterolu frakcji lipoprotein o niskiej gęstości u otyłych dzieci

\author{
${ }^{1}$ Marcela Maria Pandolfi, ${ }^{2}$ Jane de Eston Armond, ${ }^{2}$ Carolina Nunes França, \\ ${ }^{2}$ Fabiana Salatino Fangueiro, ${ }^{2}$ Luiz Henrique da Silva Nali, ${ }^{2}$ Ana Paula Ribeiro, \\ ${ }^{2}$ Patricia Colombo-Souza \\ ${ }^{1}$ Medicine Graduation Course, Santo Amaro University, São Paulo, Brazil \\ ${ }^{2}$ Post-graduation Program in Health Sciences, Santo Amaro University, São Paulo, Brazil
}

\begin{abstract}
Introduction: The increase in the prevalence of obesity and obesity in children is a pattern of the last decades. This public health issue results in metabolic disorders such as dyslipidemia with increased LDL-C. Previous findings shows that most of the Brazilian children does not follow the recommended consumption of fruits and vegetables.

Aim of the study: To evaluate the association of dietary intake characteristics with elevated serum cholesterol from low density lipoprotein in obese children.

Material and methods: Cross-sectional study involving 137 obese children (5-10 years). The mean age of the studied children was 8.27 years, $55.5 \%$ were male The weight measurements were performed on a digital anthropometric scale. The body mass index was calculated for each child and the Food Frequency Questionnaire was applied. The peripheral blood was collected for lipid profile analysis. Stata 12.0 statistical package was used to analyze the data, considering a significance level of $p<0.05$.

Results: The prevalence of hypercholesterolemia based on the serum cholesterol from low density lipoprotein fraction was $14.6 \%$. It was observed that children in the group who consumed the lower difference of risky and protective foods on a daily basis were not less likely to have a high cholesterol from low density lipoprotein level as a criterion for hypercholesterolemia $(p=0.218)$.

Conclusions: A large proportion of the individuals presented levels of lipid profile classified as undesirable for age, as well as food rich in components capable of increasing this profile, which should encourage the intensification in measures of prevention of cardiovascular diseases since childhood.
\end{abstract}

Key words:

obesity, child, lipids, eating behavior.

\section{Introduction}

Today, the growth in overweight rates is one of the main public health issue. The increase in the prevalence of overweight and obesity in children is a pattern of the last decades. The number of children under five years old with overweight and obesity increased from 32 million in 1990 to 41 million in 2016, the majority of them reside in developing countries [1].

As a consequence of the overweight, metabolic disorders such as dyslipidemia with increased LDL-C (LDL cholesterol fraction) circulating levels of, which occurred mainly in adulthood, have appeared in childhood. Thus, the development of atherosclerosis and the process of cardiovascular disease begin early and quietly [2, 3].

Previous studies have assessed the cardiovascular risk associated with inadequate food consumption. Brazilian data show, for example, that only $35 \%$ of the population adopts the recommended consumption of fruits and vegetables [4], which are important for preventing obesity and its comorbidities. The intake of these foods in children is also well below the recommended values [5, 6].

In fact, the dietary pattern has undergone changes in recent decades worldwide, which is well characterized by an increase in the intake of foods with high energy density, low in fiber and high in saturated fat, trans fat and simple sugars. This nutritional transition associated with physical inactivity, smoking and alcoholism results in an alarming increase in overweight and obesity rates, including children, who have increasingly 
become hostages to social changes and greater access to industrialized foods and fast foods [7, 8].

The interest in the evaluation of food groups considered to limit feeding patterns or not has been growing in child nutrition research $[9,10]$. Such knowledge can support or develop health strategies aimed at controlling and avoiding excess weight and, consequently, cardiovascular diseases.

Therefore, the aim of the study was to investigate the association of the characteristics of food consumption with the increase in serum LDL-C in obese children.

\section{Material and methods}

\section{Population}

This is a cross-sectional study of obese children from five to ten years. The children were recruited at the nutritional care clinic at the Complexo Hospitalar Wladimir Arruda (São Paulo - SP, Brazil). The inclusion criteria were: children with complete anamnesis and with a lipid profile measurement performed on the date closest to the first consultation with the nutritionist (maximum of 30 days). Children with suspected secondary causes of obesity (Cushing's syndrome or hypothyroidism), diseases with direct interference in the lipid profile (diabetes mellitus, chronic renal failure, nephrotic syndrome) and those using medication that potentially modify body composition or dosage of total cholesterol and fractions were not included in the study.

\section{Nutritional condition assessment}

Weight measurements were performed on a digital anthropometric scale (Filizola). The children were weighed on standing position, without shoes and wearing light clothing. Height measurements were performed using a $0.1 \mathrm{~cm}$ stadiometer. During the child's measurement, the back was kept straight and the feet parallel with four points of contact with the plane (feet, buttocks, back and occipital region). The look was directed at the horizon line, respecting the Frankfort line.

The body mass index (BMI) expressed in $\mathrm{kg} / \mathrm{m}^{2}$ was calculated for each child. A child with a BMI greater than or equal to the $95^{\text {th }}$ percentile was considered obese according to age and sex, according to the curves and percentile tables of the body mass index of the Centers for Disease Control and Prevention (CDC) [11]

The interviews and measurements were carried out by a single trained observer after setting standards defined by a panel of child nutrition specialists.

\section{Lipid profile evaluation}

The Food Frequency Questionnaire - FFQ was applied to assess the relation of food intake and possible development of chronic diseases. To estimate the lipid profile, peripheral blood was collected and sent to and analyzed by the University of Santo Amaro Laboratory. The examination was carried out by the enzymatic method and with children fasting for 12 hours. Reference values were used according to the table below, fol- lowing the I Guideline for the Prevention of Atherosclerosis in Childhood and Adolescence [12]

\section{Statistical analysis}

Hypercholesterolemia was considered by the presence of LDL-C fraction values above $130 \mathrm{mg} / \mathrm{dl}$ [13].

To analyze significance of the variables, consistency analyzes and univariate and bivariate descriptive statistics were performed. To quantify chance in associations, the $\chi^{2}$ test [14] was used.

The effect of the characteristics of food consumption on hypercholesterolemia was studied considering the difference between the consumption of risky foods and the consumption of protective foods. Protective foods were considered: fruits, vegetables and whole grains; and high-risk foods: whole milk products (cheese, curd); animal fats (lard, bacon, butter, crackling); vegetable fats (margarine); fried foods (potatoes, pastries, snacks); derived products (sausages, sausage, hamburger, meat-based preparations) and stuffed cookies. The Food Frequency Quantitative Questionnaire (QQFA) was used to assess food consumption. For each food item of the QQFA there are categories of frequency of consumption that characterize the absence of consumption "never" until "daily" and the number of times that food item was consumed on the day of consumption, which ranges from "one" to "six times/day".

The sample was divided equally into 3 strata according to this difference (negative or minimal, moderate and high difference).

For the control of confounding variables, a multivariate model of logistic regression was adjusted with estimates of odds ratios [odds ratio (OR)] for risk factors between groups of children with and without hypercholesterolemia according to the serum levels of the LDL-C [15].

The criteria for choosing the variables for composing the final models was the level of significance with a $p$-value less than 0.20 in the bivariate analysis. In addition, control variables were those with a plausible effect on the children's LDL-C level (gender, age, physical activity and difference between the consumption of risky and protective foods).

The maximum level of 0.05 was chosen to indicate a statistically significant association, this being the criterion used to remain in the final models. The statistical package used was Stata 12.0 [16].

\section{Ethical aspects}

Parents or guardians signed an informed consent form to authorize children's participation in the project. The study was approved by the research ethics committee of Universidade Santo Amaro protocol\#912009, following the requirements of the Declaration of Helsinki.

\section{Results}

A total of 137 children were enrolled in the study. The average age of the children was 8.27 years (95\% Cl: $8.0-8.56)$, The 
prevalence of hypercholesterolemia based on the serum level of the LDL-C fraction was 14.6\% (95\% Cl: 8.6-20.6\%).

We assessed the risk factors associated with hypercholesterolemia (cholesterol > $170 \mathrm{mg} / \mathrm{dl}$ ) in the obese patients evaluated and the following variables were statistically significant, regardless of the measure of association used: "Street food", "Eating in front to TV", "Breakfast", "Family History" and "Breastfeeding", with the prevalence ratio showing more conservative point estimates and more compact intervals in relation to the ratio of chances of cholesterol above the normal value for this group (Table I).

Regarding the analysis of risk factors associated with hypercholesterolemia (LDL > $130 \mathrm{mg} / \mathrm{dl}$ ) in the obese patients evaluated, the following variables were statistically significant, regardless of the association measure used, "Street food", "Having a video game" and "Breastfeeding", with the prevalence ratio showing more conservative point estimates and more compact intervals in relation to the odds ratio of the LDL fraction above the normal value for this group (Table II).

Data of hypercholesterolemia based on the serum level of total cholesterol and LDL-C fraction, revealed that children from the group who consumed the smallest difference in risky and protective foods daily were less likely to have a high level of total cholesterol $(p=0.044)$. However, there was no statistically significant difference when using the LDL-C fraction level as a criteria for hypercholesterolemia $(p=0.218)$.

\section{Discussion}

The assessment of the population's health and living conditions should take into account the children's nutritional situation associated with basic needs such as sanitation, access to health services, wealth and education $[17,18]$.

Studies in Latin America have shown that there has been an increase in the consumption of fats in recent years, specially from animal origin, in addition to the high participation of sugar in the diet. A similar pattern was found in Brazil, between the years 1961-1963 and 1999-2001 for fats (from $15.7 \%$ to $26.3 \%$ of total calories) and sugar (from 18\% to $18.8 \%$ of total calories) [19].

It is known that school lunches are extremely important to fulfill the nutritional requirements of children in school. In this sense, the consumption of school meals (also considered as another lunch or another dinner, due to its components), may be associated with obesity [20]. In addition, in recent years, there has been a change in the pattern of food consumption among children and adolescents, where an increase in the consumption of snacks is observed, representing $25 \%$ of daily energy intake and contributing to the increase in childhood obesity [21, 22].

Most of the obese children studied (51.3\%) attended to school from 7:00 am to $12: 00 \mathrm{pm}, 33.8 \%$ from $1: 30 \mathrm{pm}$ to 6:30 pm. These children probably had lunch or dinner twice, since the school offered a "lunch" at 9:40 am for the morning shift and a "dinner" at 3:20 pm for the afternoon shift. No studies were found relating obesity and school hours.
Also, $63 \%$ of obese children bought food on the street. Street food is what the child buys in establishments near the school, bakeries and pastry shops around the house. Of the 54 children who bought food on the street, $63.0 \%$ did so three times a week or more. The most consumed foods were: candies, lollipops and gum (81.5\%), fried snacks (pastry and coxinha) (64.8\%), packaged snacks (51.8\%), hot dogs (22.2\%) and stuffed wafer (13.0\%). A study conducted by Pérez-Rodrigo et al., [23] evaluated the dietary pattern of Spanish children and adolescents, taking into account a healthy or not healthy standard of living. The authors found that both boys and girls belonging to the healthy group had a higher consumption of vegetables, fruits, fish, yogurt and water, when compared to the unhealthy group, although there were no differences in the prevalence of overweight and obesity between the two groups. Another study that aimed to understand the eating behavior of Spanish and Norwegian children, described distinct eating behaviors, which highlights the need for directed nutrition advices [27]. Indeed, eating behavior is a major issue in many regions as well as observed in Brazil [28, 29].

The years of potential life lost (YPLL) by this population, up to 70 years is 8704.81 days for diseases of the circulatory system and 1947.01 days for vascular diseases.

We described a high level of cholesterol in the children of this study, which is higher than normal. It is worth noting that this study was carried out with children who attended an educational group at an outpatient clinic located in a region of the municipality of São Paulo, where there is early morbidity/mortality from cardiovascular and/or vascular brain diseases [24].

The results presented here show the need for dietary guidance and encouragement to adopt a healthy lifestyle at an increasingly early age, highlighting the importance of childcare by the pediatrician, the care provided by the general practitioner integrated into the teams of the Family Health Support Centers (NASF) where nutritionists, physical educators, psychologists and pediatricians are present. The work of the interdisciplinary team is extremely important, with a view to reducing the frequency of obesity and its consequences such as cardio and vascular brain diseases, especially in this region where they affect the population early.

The school also plays an important role in guiding children's food, monitoring canteens and the quality of food offered by them and the school itself [26]. Conscious food consumption at school promotes the adoption of healthy habits that will be discussed and taken to the family [26].

\section{Concluding remarks}

Many obese children of 5-10 years-old in Brazilian population present serum lipid profile classified as undesirable for age as well as food rich in components capable to exacerbate this lipid imbalance. They should be encouraged to intensify measures for early prevention of future cardiovascular disease. 


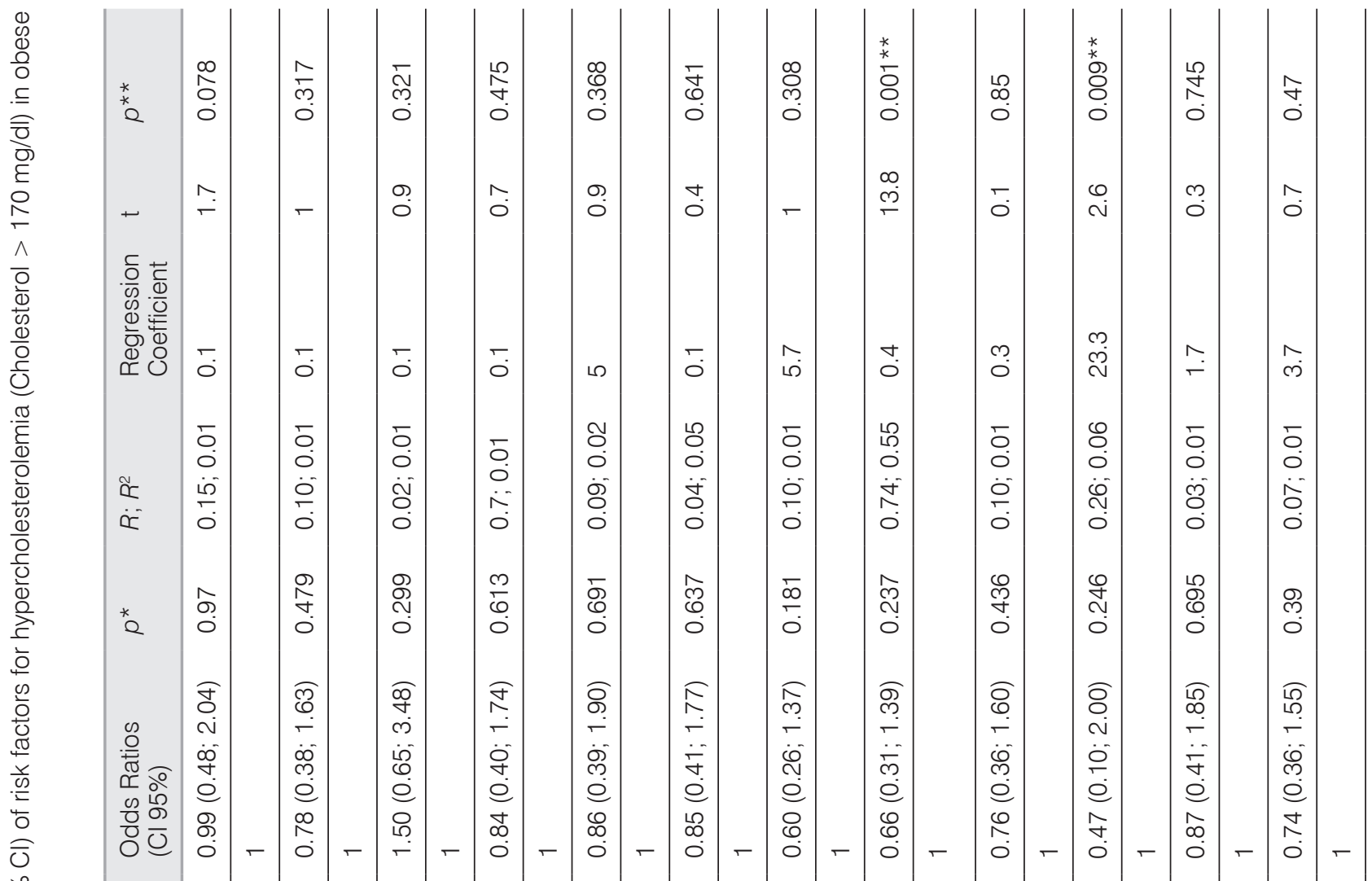

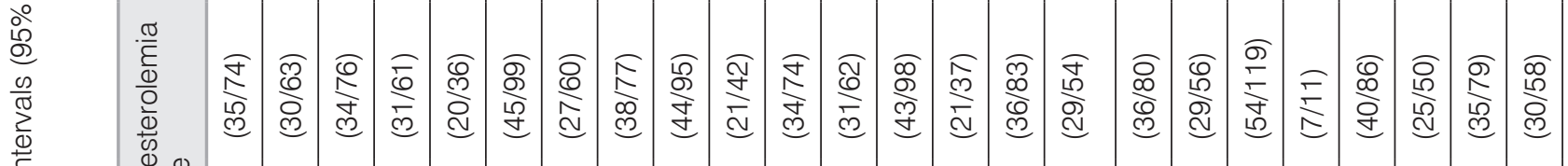

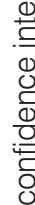
离 $\frac{1}{0} \stackrel{0}{O}$

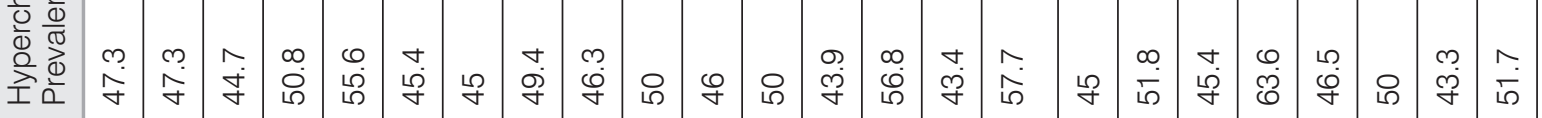

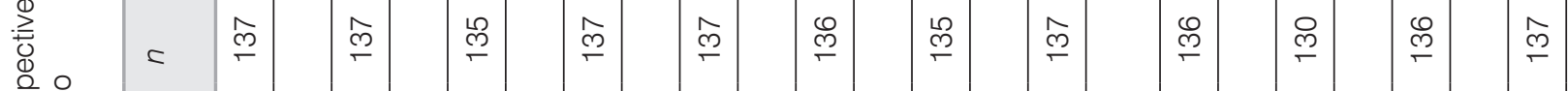
की 을

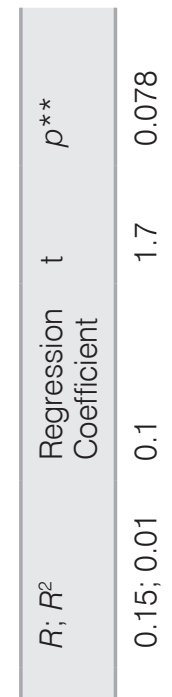
妾 3 完 $\frac{\infty}{0} \frac{8}{0}$ 잉 बi 这离 递

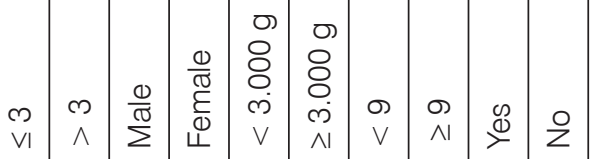

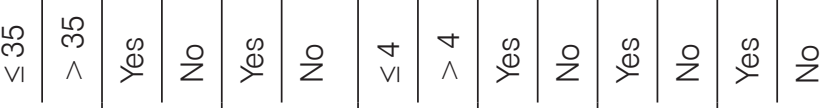
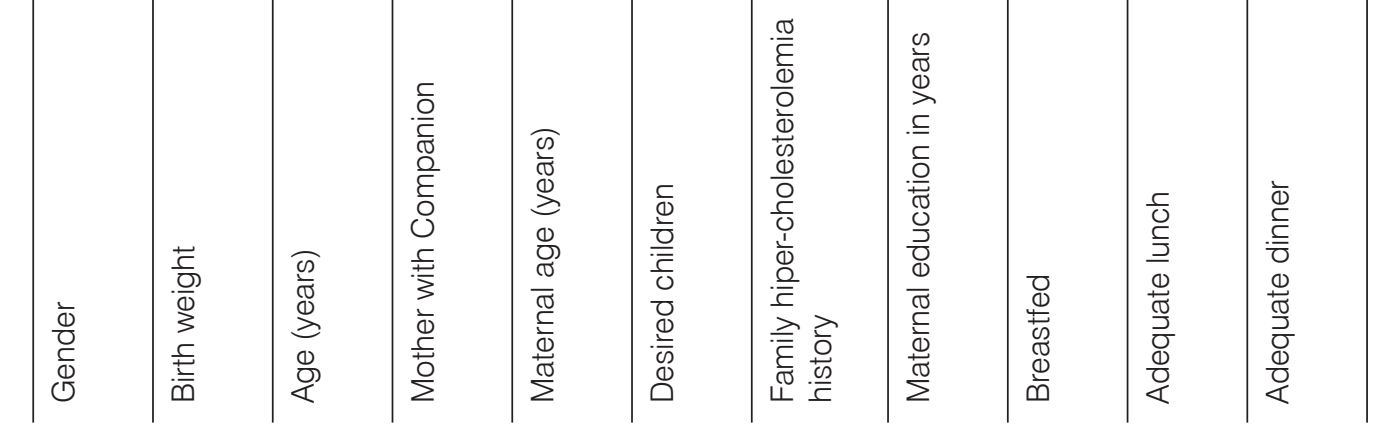


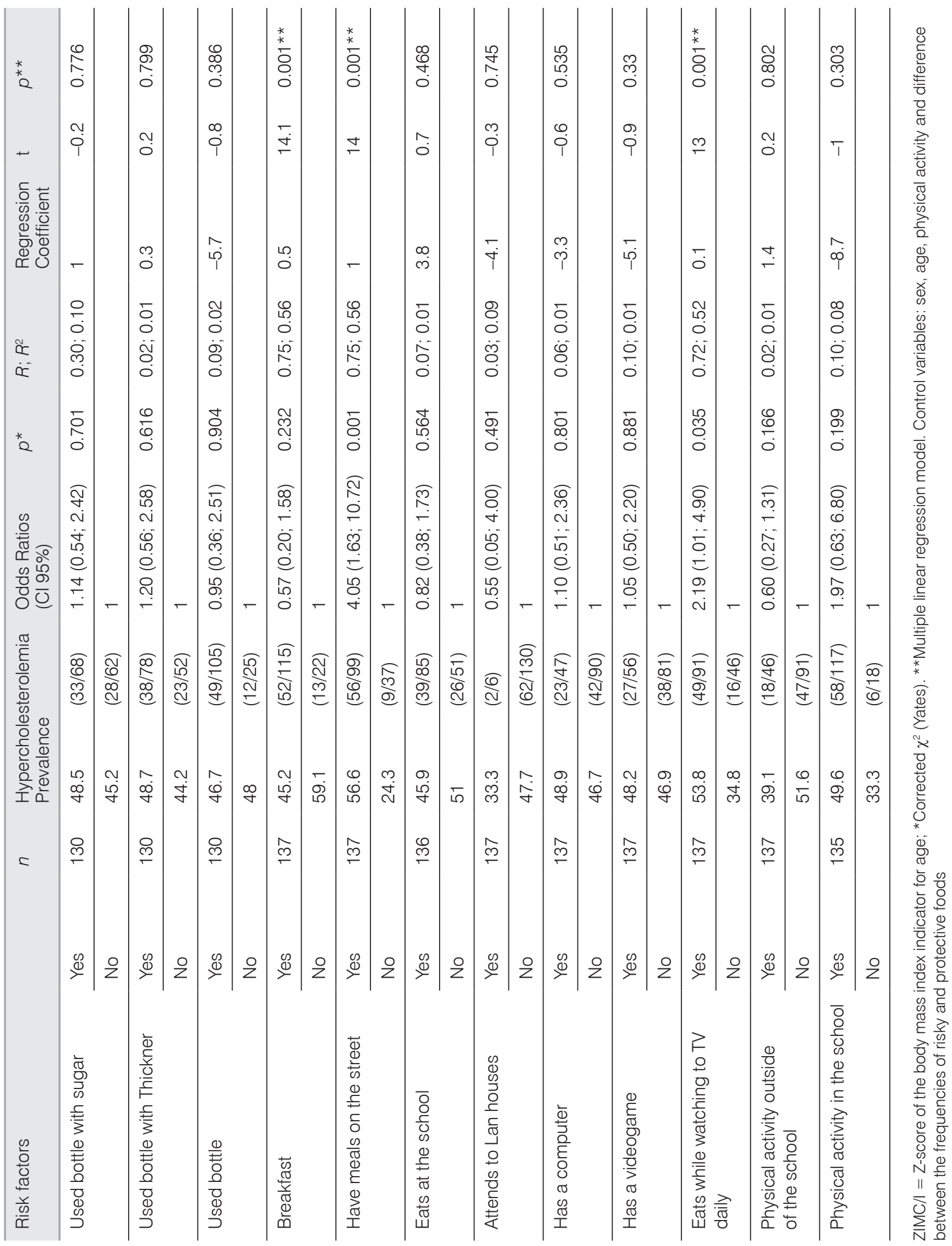




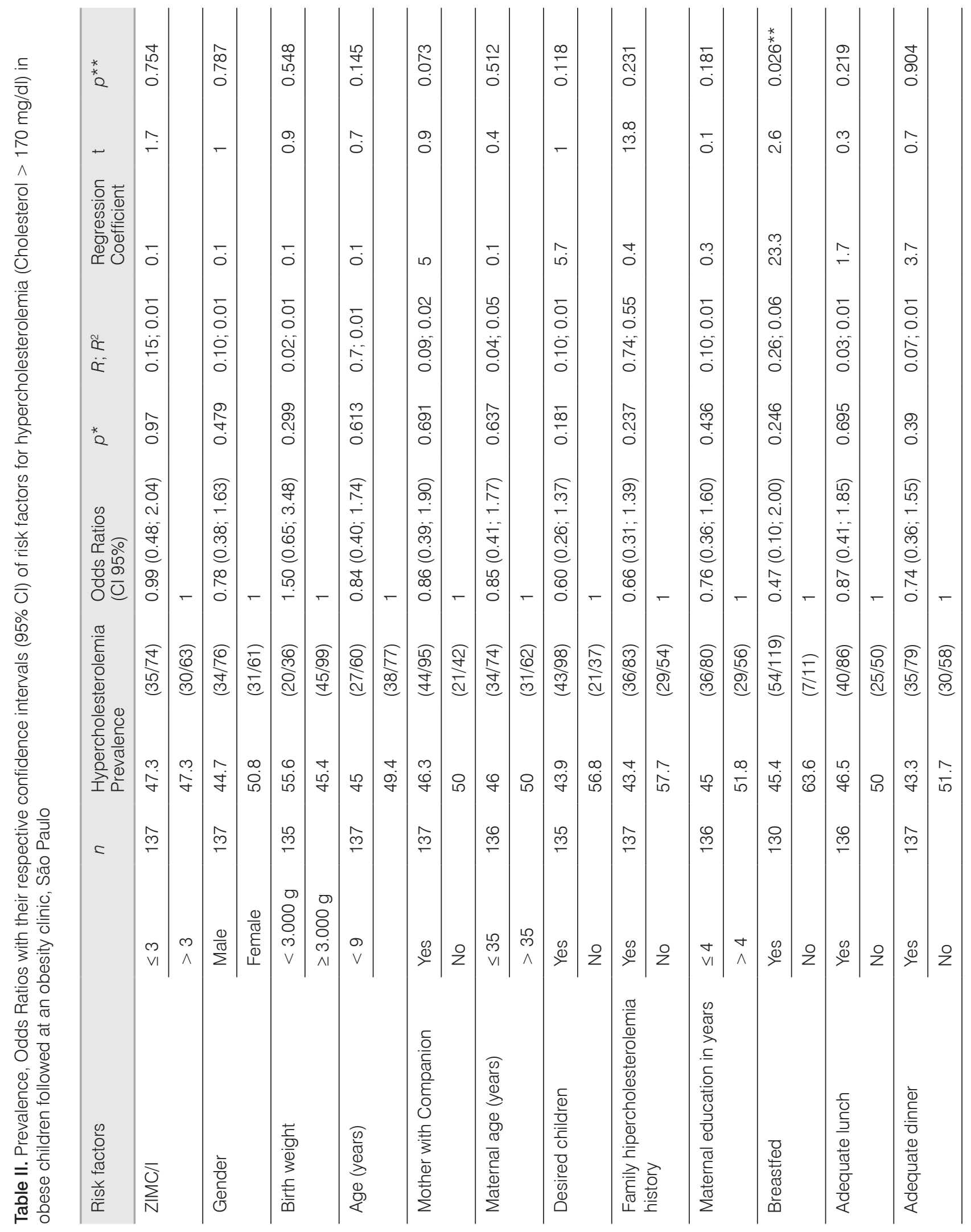




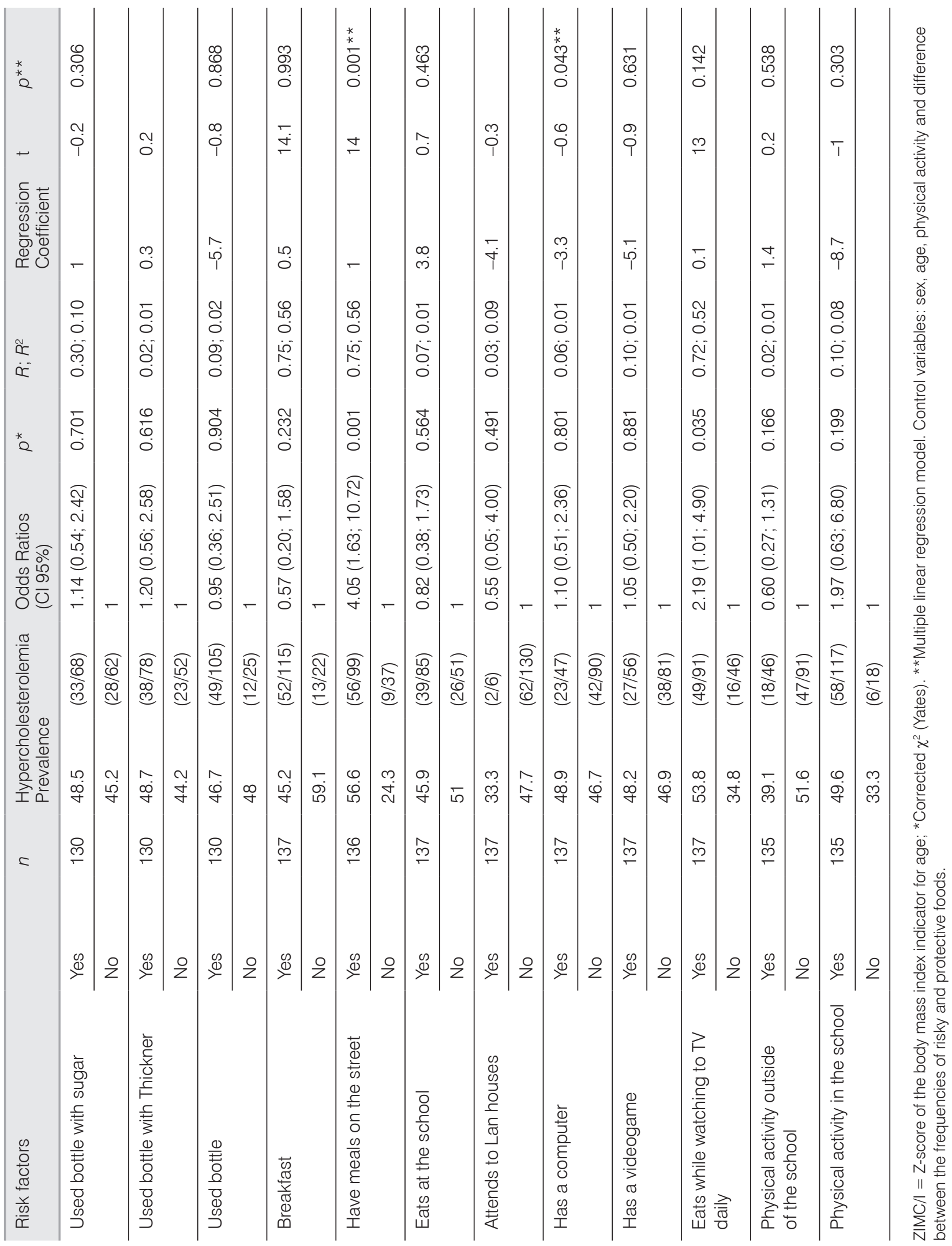




\section{References}

1. World Health Organization. New global estimates of child and adolescent obesity released on World Obesity Day. WHO; 2017 [acess in November 10th, 2017]. Available at: http://www.who.int/ end-childhood-obesity/en/.

2. Peters RJ. Atherosclerosis should be a rare disease in the lives of children born today. Neth Heart J 2017; 25: 227-228. doi: 10.1007/ s12471-017-0976-1.

3. Chen LH, Zhu WF, Liang L, et al. Relationship between glycated haemoglobin and subclinical atherosclerosis in obese children and adolescents. Arch Dis Child 2014; 99: 39-45. doi: 10.1136/archdischild-2013-303967.

4. Ministério da Saúde. Vigitel Brasil 2016: Vigilância de fatores de risco e proteção para doenças crônicas por inquérito telefônico. Brasília; 2017. [acess in November 10th, 2017]. Available at: http://portalarquivos.saude.gov.br/images/pdf/2017/junho/07/vigitel 2016 jun17.pdf.

5. Zalewska M,' Maciorkowska E. Selected nutritional habits of teenagers associated with overweight and obesity. Peer J 2017; 5 : e3681. doi: 10.7717/peerj.3681.

6. Mondini L, Levy RB, Saldiva SRDM, et al. Prevalência de sobrepeso e fatores associados em crianças ingressantes no ensino fundamental em um município da região metropolitana de São Paulo, Brasil Cad Saúde Pública, Rio de Janeiro 2007; 23: 1825-1834. doi: 10.1590/s0102-311×2007000800009.

7. Bu SY. Transitional changes in energy intake, skeletal muscle content and nutritional behavior in college students during coursework based nutrition education. Clin Nutr Res 2013; 2:125-134. doi: 10.7762/cnr.2013.2.2.125

8. Hoffman DJ, Klein DJ. Growth in transitional countries: the longterm impact of under-nutrition on health. Ann Hum Biol 2012; 39 (5): 395-401. doi: 10.3109/03014460.2012.705893.

9. Appannah G, Pot GK, Oddy WH, Jebb SA, Ambrosini GL. Determinants of a dietary pattern linked with greater metabolic risk and its tracking during adolescence. J Hum Nutr Diet 2018; 31 (2): 218-227 doi: 10.1111/jhn.12519.

10. Appannah G, Pot GK, Huang RC, et al. Identification of a dietary pattern associated with greater cardiometabolic risk in adolescence. Nutr Metab Cardiovasc Dis 2015; 25 (7): 643-650.

11. National Center for Health Statistics. New pediatric growth charts provide tool to ward off future weight problems. HHS News. May 20, 2000. [acess in November 11th, 2017]. Available at: http://www. cdc.gov/nchs/pressroom/00news/growchrt.htm

12. Giuliano IC, Caramelli B, Pellanda L, et al. I Diretriz de Prevenção da Aterosclerose na Infância e na Adolescência. Arq Bras Cardiol 2005; 85 Supl 6: 3-36.

13. Xavier HT, Izar MC, Faria Neto JR, et al. V Diretriz Brasileira de Dislipidemais e Prevenção de Aterosclerose. Arquivos Brasileiros de Cardiologia 2013; 101 (4): supl 1

14. Kirkwood BR, Sterne JAC. Chi-squared tests for $2 \times 2$ and larger contingency tables. In: Kirkwood BR, Sterne JAC. Essential medical statistics. $2^{\text {nd }}$ ed. Blackwell Science, Malden, Mass 2003; 165-176.
15. Kleinbaum DG, Kupper LL, Muller KE, Nizam A. Applied regression analysis and other multivariable methods. $3^{\text {rd }}$ ed. Duxbury Press, Pacific Grove 1998.

16. Stata Statistical Software: Release 12 [program]: StataCorp LP, 2011.

17. Peele P, Keyser D, Lovelace J, Moss D. Advancing Value-Based Population Health Management Through Payer-Provider Partnerships: Improving Outcomes for Children With Complex Conditions. J Healthc Qual 2018; 40: e26-32. doi: 10.1097/JHQ. 0000000000000101.

18. Monteiro CA, Mondini L, Souza ALM, Popkin BN. Da desnutrição para a obesidade: a transição nutricional no Brasil. In: Monteiro CA, editor. Velhos e novos males da saúde no Brasil: a evolução do país e suas doenças. $1^{\text {st }}$ ed. Hucitec, São Paulo 1995; 247-255.

19. Monteiro CA, Conde WL, Popkin BM. Incomespecific shifts in obesity in Brazil: 1975-2003. Am J Public Health 2007; 97: 1808-1812. doi: 10.2105/AJPH.2006.099630.

20. Brasil - Ministério da Educação - MEC [homepage on the Internet]. Fundo Nacional de Desenvolvimento da Educação (FNDE) - Alimentação Escolar [acesso in November 11 ${ }^{\text {th }}, 2017$ ]. Available at: http://www.fnde.gov.br/.

21. Hutchinson JM, Watterworth JC, Haines J, et al. Snacking patterns of preschool-aged children: Opportunity for improvement. Can J Diet Pract Res 2018; 79: 2-6. doi: 10.3148/cjdpr-2017-022.

22. Wang $L$, van de Gaar VM, Jansen W, et al. Feeding styles, parenting styles and snacking behaviour in children attending primary schools in multiethnic neighbourhoods: a cross-sectional study. BMJ Open 2017; 7 (7): e015495. doi: 10.1136/bmjopen-2016-015495.

23. Pérez-Rodrigo C, Gil Á, González-Gross M, Ortega RM, et al. Clustering of Dietary Patterns, Lifestyles, and Overweight among Spanish Children and Adolescents in the ANIBES Study. Nutrients 2015; 8 (1): pii: E11.

24. Secretaria de Saúde da cidade de São Paulo. Boletim Eletrônico da CEInfo. Edição especial Aspectos da mortalidade no município de São Paulo, 2013.

25. Cervato-Mancuso AM, Faria Westphal M, Lie Araki E, Bógus CM. Rev Paul Pediatr 2013; 31: 324-330.

26. Cervato-Mancuso AM, Rosendo Vincha KR, Santiago DA. Educação Alimentar e Nutricional como prática de intervenção: reflexão e possibilidades de fortalecimento. Physis Revista de Saúde Coletiva 2016; 26: 225-249.

27. Rodríguez-Borjabad C, Narveud I, Christensen JJ, et al. Dietary intake and lipid levels in Norwegian and Spanish children with familial hypercholesterolemia. Nutr Metab Cardiovasc Dis 2021; 31 : 1299-1307. doi: 10.1016/j.numecd.2020.12.002.

28. Zubin Maslov P, Hill JA, Lüscher TF, Narula J. High-sugar feeding and increasing cholesterol levels in infants. Eur Heart J 2021; 42 : 1132-1135. doi: 10.1093/eurheartj/ehaa868.

29. Power TG, Hidalgo-Mendez J, Orlet Fisher J, et al. Obesity risk in Hispanic children: Bidirectional associations between child eating behavior and child weight status over time. Eat Behav 2020; 36: 101366. doi: 10.1016/j.eatbeh.2020.101366. 